\title{
THE EFFECT OF DICTOGLOSS METHOD TOWARDS STUDENTS' LISTENING COMPREHENSION AT THE SECOND GRADE OF SMA NEGERI 16 BATAM
}

\author{
Albert Efendi Phn \& Linda Uli Napitupulu \\ Program Studi Pendidikan Matematika UNRIKA Batam
}

\begin{abstract}
Listening is one of the most important skill since more than $45 \%$ of communicating time is spent listening. Based on that fact, teacher should put high concern on applying effective teaching strategies to develop listening ability. Dictogloss method can give benefit to develop the students' listening comprehension. It involves top-down and bottom-up activities which encourage students to hear some sounds, hold them in their working memory, and then interpret what they've just heard before something new comes along. At the same time, listeners are using their background knowledge.

The problems solved in this study were that students still got difficult in understanding spoken English, most of students did not understand the instruction when teacher used spoken English, and some teachers still used conventional method to teach listening. This study used the design of pre-experimental. The subject of the study was the second grade students' of SMA Negeri 16 Batam. The experimental group was taught listening by using dictogloss method, while the control group got treatment from the teacher's conventional method.

The result of the test was analyzed by using t-test formula with the significance level 5\%. From the analysis, the writer found that $\mathrm{t}$-test was greater than $\mathrm{t}$-table, namely $14.45>1,980$. Thus, it can be concluded that there is a significant effect of dictogloss method towards students' listening comprehension.

Based on the result of this research, it is concluded that there is a significant effect of dictogloss method towards students' listening skill at the second grade of SMA Negeri 16 Batam in academic year 2013/2014. The research finding implies that dictogloss method is applicable to increase the second grade students of senior high school's listening comprehension. The activity of dictogloss can be as input in scheduling listening class of the English curriculum for Senior High School. This method might give contribution to support students' skill in writing. Therefore, the writer suggests the English teacher should use dictogloss method to teach listening, the other researchers are suggested to carry out further studies about the use of dictogloss method and the other strategy in developing students' listening comprehension, and students should learn how to accommodate differences in ability.
\end{abstract}

Key words: Dictogloss Method, Listening Comprehension

\section{INTRODUCTION}


Nowadays, for senior high school, listening skills are extremely important. Developing the listening is one of the most important language skills before students are ready to learn speaking, reading, and writing. Improving students' listening skill is necessary especially at the present time since English teachers spend much time on strengthening students' reading abilities. Meanwhile, mastering listening is very important since more than $45 \%$ of communicating time is spent listening, which clearly shows how important this skill in overall language ability (Feyten in Vasiljevic, 2010:41). But in this importance of listening mastery, it was still found that the students got difficult in understanding spoken English, most of students did not understand the instruction when teacher uses spoken English, some teachers still used conventional method to teach listening.

The students got difficult in understanding spoken English, most of students did not understand the instruction when teacher uses spoken English, and some teachers still used conventional method to teach listening. Based on the reasons above, the writer was interested to find out the effect of this method through the research entitled "The Effect of Dictogloss method towards Students' Listening Comprehension at the Second Grade of SMA Negeri 16 Batam in Academic Year2013/2014".

\section{FORMULATION OF THE STUDY}

Based on the problem above, the study was formulated as follow: "Is there any significant effect of dictogloss method towards students' listening comprehension?"

\section{REVIEW OF LITERATURE}

Listening comprehension is the ability to identify and understand what others are saying. Listening to understand speech involves a number of basic processes, some depending upon linguistic competence, some depending upon previous knowledge that is not necessarily of a purely linguistic nature and some depending upon psychological variables that affect the mobilization of these competences and knowledge in the particular task situation. The listener must have a continuous set to listen and understand, and as he hears the utterance, he may helped some kind of set to process and remember the information transmitted (Saricoban, 1999:1). According to Norfleet (2014:1), there are several factors that affect students' listening comprehension namely Speaker, Background knowledge, Speaking style, Visual input. Brown (2006:10) stated there are two kinds of strategies in teaching listening namely: Cognitive strategies and Meta-cognitive strategies.

In this study, the researcher used dictogloss method in increasing students' listening comprehension. Dictogloss method is a classic activity where we are required to reconstruct a text by listening and noting down key words which are then used as a base for reconstruction (Vasiljevic, 2010:41). The study used multiple choice test type to assess the listening skills as Brown (2006:6) stated namely students could listen for the main idea, students could listen for details, students could listen is listening and making inferences. In doing the listening assessment, the researcher used all the three indicators to assess the students' listening comprehension. In the study, the total scores on the multiple-choice section were obtained by counting the raw scores. Raw scores are obtained simply by counting the number of right answer (Harris, 1969:121).

\section{POPULATION AND SAMPLE OF THE RESEARCH}


The population in this research was the second grade students of SMA Negeri 16 Batam in Academic year 2013/2014. Totally the population in SMA Negeri 16 in second grade was 105 students. It was divided into three classes namely class XI IPS 1(38 students), XI IPS 2 (37 students), and XI IPA (30 students). From these classes, it was taken two sample classesexperimental class and control class. The experimental class was the XI IPS 2 class which consists of 37 students, and the control class was XI IPS 1 which consists of 38.

\section{TECHNIQUE OF COLLECTING DATA}

In this research, the researcher used test as the instrument of the research. The researcher gave pre-test and post-test in the experimental class. Pre-test was given to the students in order to find out the students' listening comprehension before treated by using dictogloss method. The test used Multiple choice format in which the learners have a list of multiple-choice questions in front of them while they listen to a text being read or a recorded dialogue. After figuring out the students' ability, the researcher taught listening by using dictogloss method. Then the researcher examined the students' listening comprehension after treated by dictogloss method by giving post-test, the same test as in pre-test. The result of both pre-test and post-test was collected in order to be analyzed as the result of before and after using Dictogloss method as a learning method.

\section{RESEARCH FINDING}

1. Pre-test of experimental group

Diagram 1.The percentage of experimental group pre-test

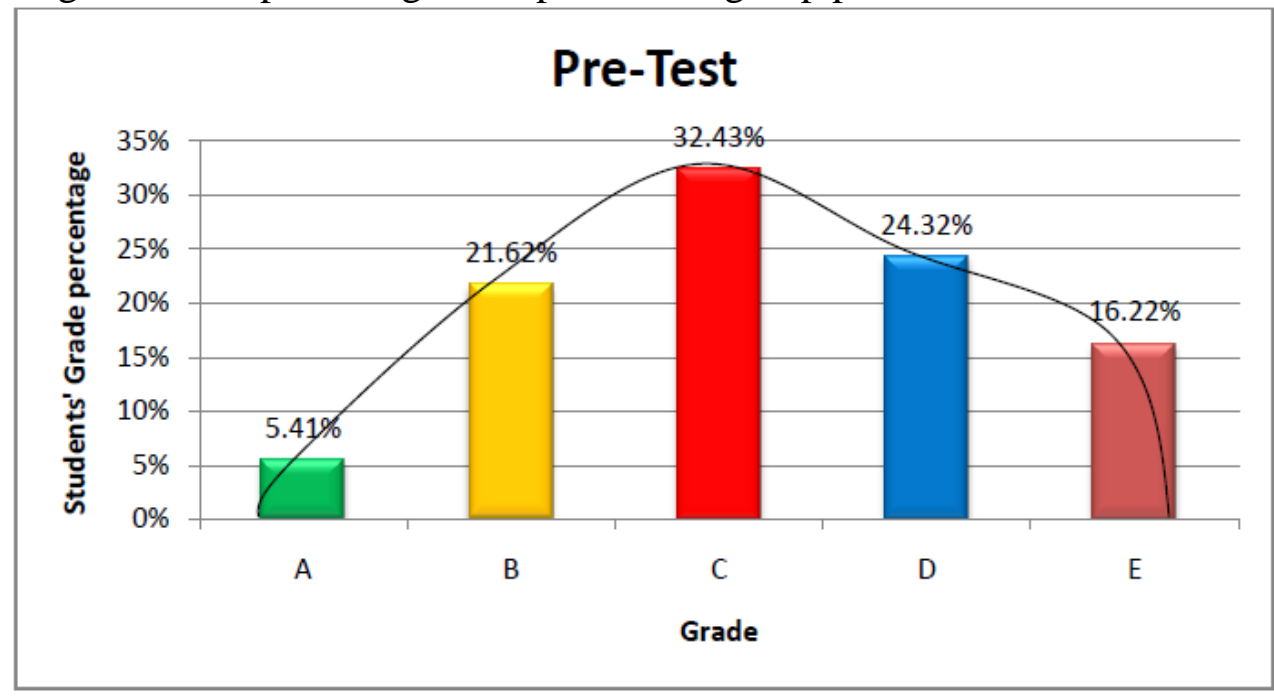

The chart above is based on the data below:

Table 4.1: pre-test data of the experimental group

\begin{tabular}{|c|c|c|c|}
\hline Grade & Interval & Frequency & $\%$ \\
\hline A & $80-100$ & 2 & $5.41 \%$ \\
\hline B & $70-79$ & 8 & $21.62 \%$ \\
\hline C & $60-69$ & 12 & $32.43 \%$ \\
\hline D & $50-59$ & 9 & $24.32 \%$ \\
\hline E & $30-49$ & 6 & $16.22 \%$ \\
\hline
\end{tabular}


Based on the diagram presented above, illustrated that before given treatment by dictogloss method, the number of students who got grade $\mathrm{C}$ was the highest namely $32.43 \%$ (12 students), while the number of students who got grade A was the lowest namely $5.41 \%$ (2 students). In this pre-test, the mean score was 57.29 with the highest score 90 and the lowest score 30 (see appendix 8).

2. Post-test of experimental group

Diagram 2.The percentage of experimental group post-test

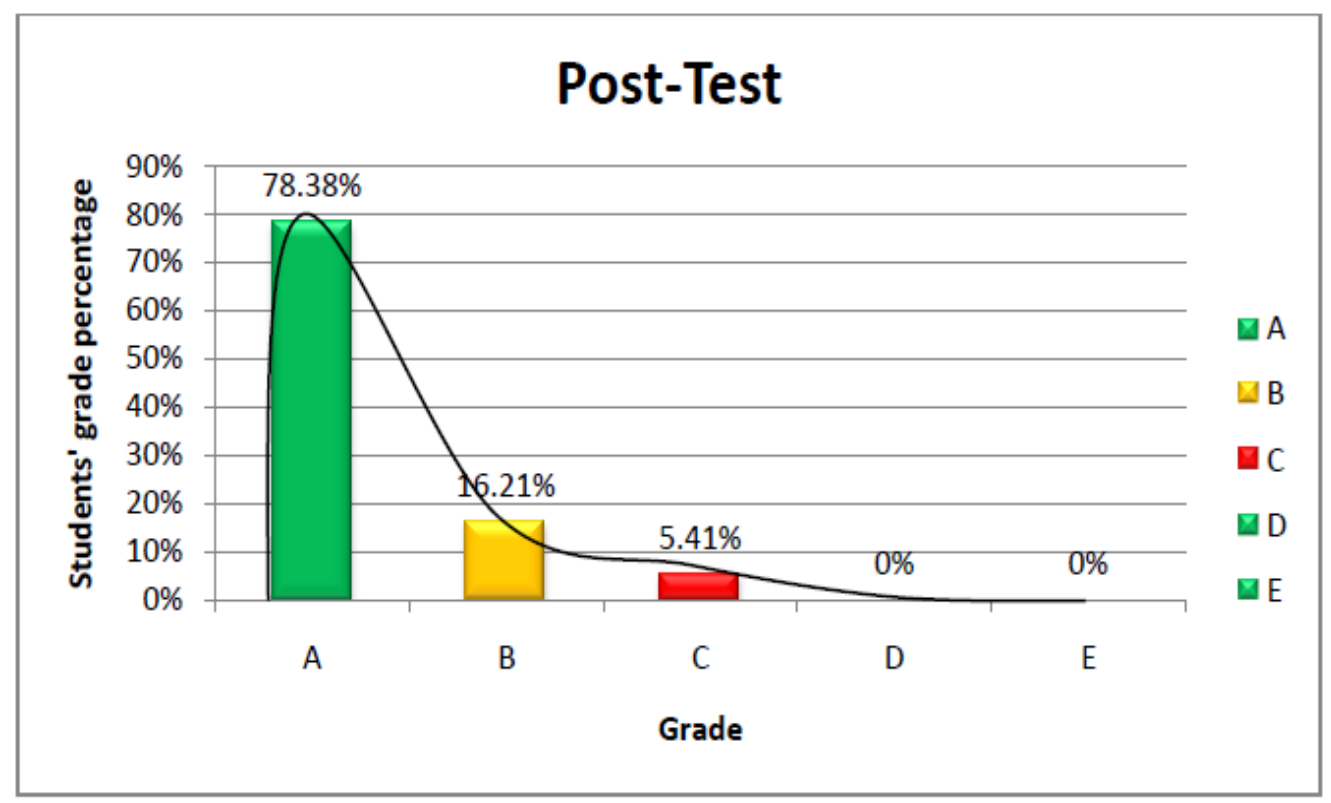

The chart above is based on the data below:

Table 4.2: post-test data of the experimental group

\begin{tabular}{|c|c|c|c|}
\hline Grade & Interval & Frequency & $\%$ \\
\hline A & $80-100$ & 29 & $78.38 \%$ \\
\hline B & $70-79$ & 6 & $16.21 \%$ \\
\hline C & $60-69$ & 2 & $5.41 \%$ \\
\hline D & $50-59$ & 0 & $0 \%$ \\
\hline E & $30-49$ & 0 & $0 \%$ \\
\hline
\end{tabular}

Based on the diagram presented above, illustrated that before given treatment by dictogloss method, the number of students who got grade A is the highest namely $78.38 \%$ (29 students), while the number of students who got grade $\mathrm{C}$ is the lowest namely $5.41 \%$ (2 students). And there is not at all student who got D and E.

In this post-test, the mean score was 82.97 with the highest score 100 and the lowest score 60 (see appendix 8).

3. Pre-test of control group

Diagram 3.The percentage of control group 


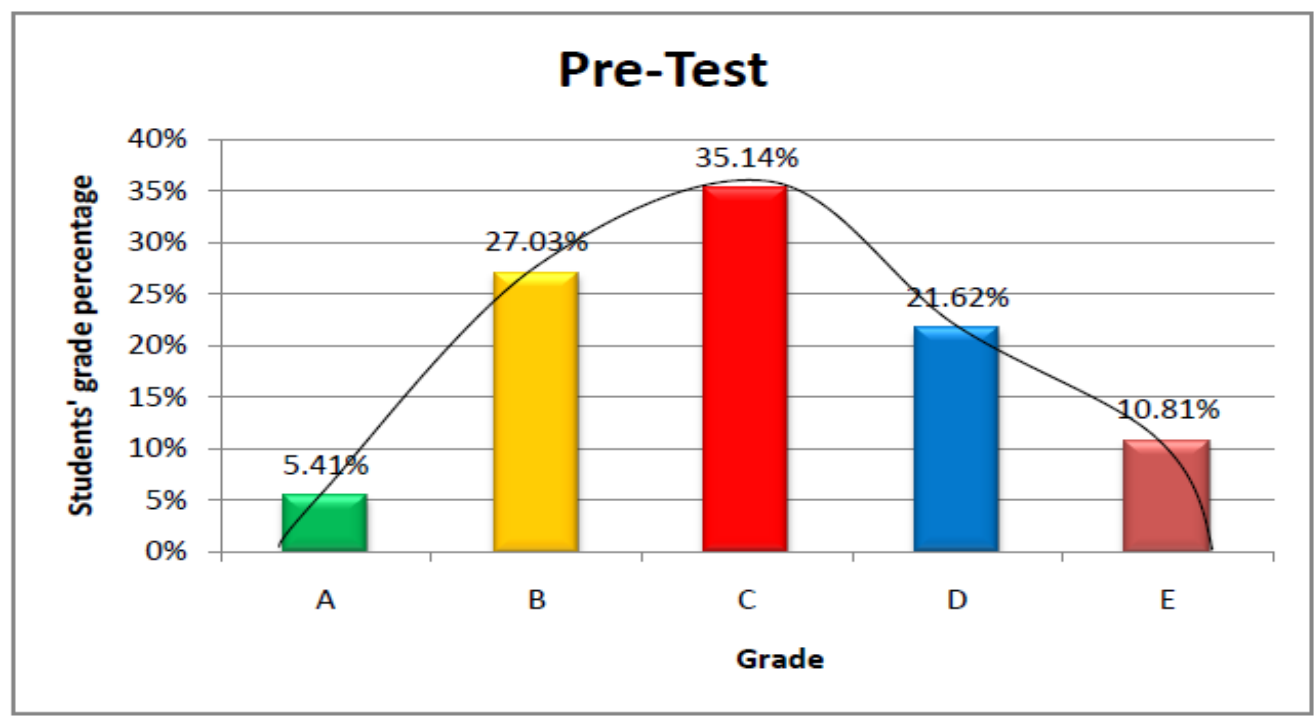

The chart above is based on the data below:

Table 4.3: pre-test data of the control group

\begin{tabular}{|c|c|c|c|}
\hline Grade & Interval & Frequency & $\%$ \\
\hline A & $80-100$ & 2 & $5.41 \%$ \\
\hline B & $70-79$ & 10 & $27.03 \%$ \\
\hline C & $60-69$ & 13 & $35.14 \%$ \\
\hline D & $50-59$ & 8 & $21.62 \%$ \\
\hline E & $30-49$ & 4 & $10.81 \%$ \\
\hline
\end{tabular}

Based on the diagram presented above, illustrated that before given treatment by dictogloss method, the number of students who got grade $\mathrm{C}$ is the highest namely $35.14 \%$ (13 students), while the students who got grade A is the lowest namely $5.41 \%$ ( 2 students).

In this pre-test, the mean score was 59.45 with the highest score 80 and the lowest score 40(see appendix 9).

4. Post-test of control group

Diagram 4.The percentage of control group Post-test

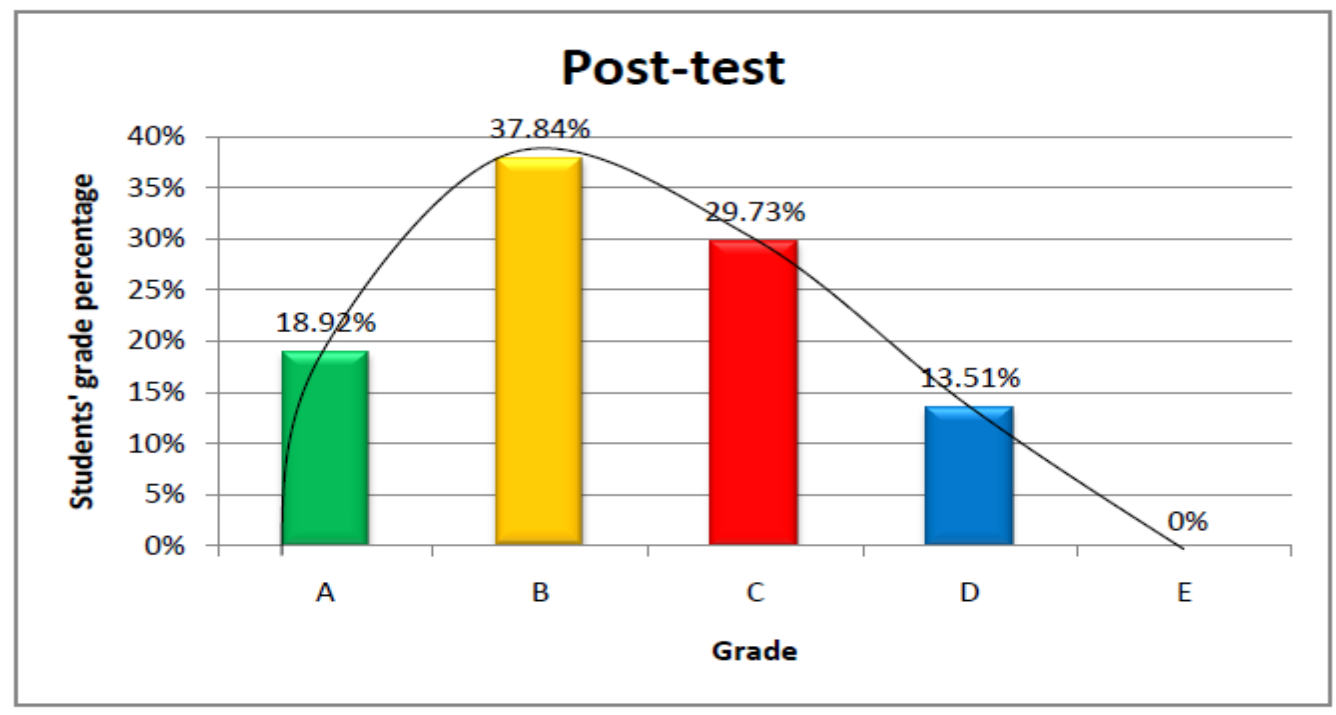


The chart above is based on the data below:

Table 4: post-test data of the control group

\begin{tabular}{|c|c|c|c|}
\hline Grade & Interval & Frequency & $\%$ \\
\hline A & $80-100$ & 2 & $18.92 \%$ \\
\hline B & $70-79$ & 14 & $37.84 \%$ \\
\hline C & $60-69$ & 11 & $29.73 \%$ \\
\hline D & $50-59$ & 5 & $13.51 \%$ \\
\hline E & $30-49$ & 0 & $0 \%$ \\
\hline
\end{tabular}

Based on the diagram presented above, illustrated that before given treatment by dictogloss method, the number of students who got grade B is the highest namely $37.84 \%$ (14 students), while the students who got grade D is the lowest namely13.51\% (5 students). And there is not at all student who got grade E.

In this post-test, the mean score was 66.21 with the highest score 80 and the lowest score 50 (see appendix 9).

\section{INTERPRETATION AND DISCUSSION}

From the research finding above, it is found that dictogloss method gives significant effect towards students' listening comprehension. Therefore, dictogloss method can be an effective way to be used in listening class. Nevertheless, the researcher found a limitation during the research namely the research can only be conducted towards the student who has higher knowledge about spoken and written English vocabulary. Most of students who were weak in vocabulary mastery got difficult to follow the method as fast as wished.

Dictogloss method constitutes one of effective ways to increase students' listening comprehension in which the students are dictated by using audio text then asked to reconstruct a text by using the key words found from the audio and maintaining the information in the reconstruction. That method encourages students to hear, hold in working memory, use their background knowledge to interpret the meaning, and drill pouring sound in written form. Since students have been familiar and used to focus on key words, students be easier to understand spoken English especially short and long spoken English passage. It helps students to be easy to familiarize spoken English vocabulary and the written form. The collaborative reconstruction task gives learners the opportunities to practice and use all modes of language and to become engaged in authentic communication. The students' practice in dictogloss method may also give contribution in students' writing skill.

\section{CONCLUSION}

Based on the result of the discussion derived from the data analysis presented in the previous chapter, it can be concluded that there is a significant effect of dictogloss method towards the students' listening comprehension. The success of this research is proved by the students' score in the pre-test and post-tests.

1. The sum score of experimental group for pre-test was 2120, while the sum score for post-test was 3070. Then, the sum score of control group for pre-test was 2260, while the sum score for post-test was 2510. It was shown that the students' score who got treatment with dictogloss method were higher than the students' who got treatments with conventional method. 
2. Statistically research of t-test was also proved that the value of t-obtained of experimental class was 15,07, while the value of t-table was 2,00 at the degree of freedom of 72 at the level of significance $5 \%$. So, it can be concluded that obtained was greater than t-table $(15,07$ $>2,00$ ) which means that teaching listening by using dictogloss method is more effective to increase students' listening comprehension than conventional method is statistically accepted.

\section{BIBLIOGRAPHY}

Ambarita, Jenri. 2011. Penerapan Konseling Pastoral terhadapPerubahan Perilaku Korban Narkoba di Rehabilitasi Nazar Ministry. Thesis. Sekolah Tinggi Theologia Global Misi.

Brown, Steven. 2006. Teaching Listening. United States of America: Cambridge University Press.

Emzir. 2012. Metodologi Penelitian pendidikan: Kuantitatif dan Kualittif. Jakarta: PT Rajagrafindo Persada.

Fatmawati. Gilang. 2013. Analisis Produk dan Kualitas Pelayanan terhadap Keputusan Pembelian di Lisung The Dego Boutique Resto Bandung. Thesis. Universitas Pendidikan Indonesia.

Harris, David P. 1969. Testing English as a Second Language. United States of America: McGraw-Hill.

L.R., Gay, dkk. 2009. Educational Research: Competencies for analysis and applications. New Jersey: Pearson Education Inc.

Margono, S. 2007. Metodologi Penelitian Pendidikan. Jakarta: Rimeka Cipta. Norfleet, Michele. 2014. Factors That Affect Listening Comprehension. (http://education.seattlepi.com, accessed date on 10th March 2014 at 21:00)

Oktaviani, Erni. 2013. Efektivitas Teknik Permainan Lompat Jingjat Untuk Meningkatkan Penguasaan Kata Bantu Bilangan Universitas Pendidikan Indonesia. Thesis. Universitas Pendidikan Indonesia.

Vasiljevic, Zorana 2010. Dictogloss as an Interactive Method of Teaching Listening Comprehension to L2 Learners. Japan: Fakulty of Literature, Bunkyo University.Vol.3.No. 1. March 2010. p. 43-45.

Rost. M. 2002. Teaching and Researching Listening. London, UK: Longman.

Saricoban, Arif. 1999. The teaching of Listening. V.5. No. 5. December 1999. P.1.

Wipf. J (1984). Strategies for Teaching Second Language Listening Comprehension. Foreign Language Annals 17:345-348. 
Patel, M.F.\& Preven M. Jain. 2008. English Language Teaching. Jaipur: Sunrise.

Borg W. \& Gall D. M. 2003. Educational Reseach. New York: Longman.

Riduwan \& Sunarto. 2012. Pengantar Statistika. Bandung: Alfabeta.

Riduwan. 2005. Statistika Pendidikan. Bandung: Alfabeta.

Wajnryb, Ruth. 1990. Grammar Dictation. Oxford: Oxford University Press. 